\title{
A odisséia de Langsdorff nas florestas do Brasil
}

\author{
Silvia F. de M. Figueirôa \\ Departamento de Geociências Aplicadas ao Ensino \\ Instituto de Geociências/Unicamp \\ Caixa Postal 6152 13081-970 Campinas — SP Brasil
}

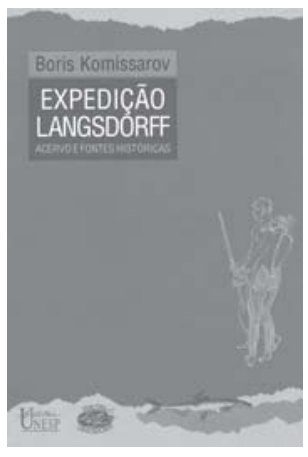

Boris Komissarov Expedição Langsdorff: acervo e fontes bistóricas

Trad. Marcos Pinto Braga São Paulo/Brasília, Ed. da Unesp/Langsdorff, 1994. 126p.
$\mathrm{O}$ livro de Boris Komissarov se propõe a fazer uma apresentação, em língua portuguesa, das fontes disponíveis na Rússia sobre a Expedição Langsdorff, que percorreu o Brasil de 1822 a 1829 a serviço do império russo. Trata-se, essencialmente, do vasto material produzido pela expedição ao longo dos quase 17 mil quilômetros palmilhados pelo chefe do grupo, o barão Georg Heinrich von Langsdorff, então ministro plenipotenciário da Rússia no Brasil, e demais participantes: Nester Rubtsov (cartógrafo), Hercule Florence, Adrien Taunay e Moritz Rugendas (desenhistas), Ludwig Riedel (botânico) e Edouard Ménétriès (zoólogo e antropólogo).

De início, cabe elogiar a iniciativa do autor, da Associação Internacional de Estudos Langsdorff e da Editora da Unesp, ao tornarem disponíveis dados preciosos e por largo tempo desconhecidos dos pesquisadores brasileiros em função mesmo da história do acervo. Infelizmente, esse tipo de instrumento de pesquisa ainda é pouco freqüente entre nós.

Komissarov estrutura o livro em seis capítulos, cada um deles dedicado a uma tipologia documental, nos quais o material é bem descrito e, muitas vezes, avaliado qualitativamente. O primeiro capítulo aborda os quatro diários dos participantes: o do próprio Langsdorff, o de Hercule Florence, o de Edouard Ménétriès e o de Ludwig Riedel. O segundo trata dos trabalhos dos membros: diferentes Memórias e relatórios de Langsdorff, a Viagem pitoresca de Florence, e manuscritos de Rubtsov e de Riedel. O terceiro relaciona a coleção de documentos (sobre a economia e populações) coletados e, sobretudo, copiados de instâncias da administração imperial brasileira pelos membros da expedição. O quarto apresenta a correspondência particular de Langsdorff, que está bastante incompleta segundo o autor, bem como a correspondência da expedição, essa sim, disponível em sua grande maioria. O quinto lista brevemente a parte cartográfica (mapas e plantas) existente no acervo, sendo que é apenas parte 
da coleção completa outrora produzida. Constitui-se basicamente dos mapas entregues por Rubtsov à Divisão Hidrográfica do Ministério da Marinha russa. O último capítulo introduz a coleção de desenhos dos três artistas da expedição, assim como reproduz vinte deles.

Merece destaque o cuidado do autor ao longo da apresentação do acervo: preocupação em averiguar a autoria dos documentos, confirmação de autenticidade, confronto com outras fontes, minúcias na descrição enriquecidas, inclusive, por transcrições parciais de alguns textos. A reprodução dos desenhos é um bom exemplo, embora, em minha opinião, se o custo da edição assim o permitisse, teria merecido melhor tratamento, como cor (quando fosse o caso do original) e papel cuchê. De qualquer forma, o principal objetivo do livro foi atingido: a leitura permite que se tenha uma boa idéia do acervo e, até mesmo, de algumas características particulares de Langsdorff.

A lamentar, no entanto, dois aspectos que não comprometem o conjunto da obra, mas para os quais o leitor deve estar atento. O primeiro deles, um certo descuido na revisão. Já na primeira orelha encontramos o rio Juruena grafado como Jurema. A localidade mineira de Gongo Soco também aparece, muitas vezes, como Congo Soco. Além disso, as localidades são mencionadas indistintamente, talvez como aparecem na documentação produzida há mais de um século e meio, o que dificulta sua localização e, por conseguinte, a compreensão, já que muitos lugarejos hoje nem mais existem, ou mudaram de nome e se tornaram cidades importantes. Apenas como um exemplo, a atual cidade de Campinas (SP), com mais de um milhão de habitantes atualmente, na época era um sítio um tanto acanhado conhecido como Vila de São Carlos. Teriam sido de grande auxílio comentários, ainda que em notas de rodapé, esclarecendo essa geografia histórica, a fim de que os leitores pudessem melhor perceber a utilidade da listagem de nomes de localidades pretéritas. Em certos trechos, há também problemas de incorreção histórica, como na p. 27: "(Langsdorff) visitou várias vezes a fábrica de ferro de Ipanema, sobre a qual deixou anotações relacionadas ao planejamento e organização da produção. Suas notas completam as informações de Eschwege, ligado à administração da empresa." Ora, Eschwege jamais se envolveu diretamente com a Fábrica de Ipanema.

O segundo problema, mais significativo, resulta da visão do autor e, em certa medida, de seu modo de conceber a história. Ao longo de todo o texto, Komissarov não se limita a analisar os documentos em sua materialidade, mas emite diversos juízos de valor problemáticos. Isso é bastante evidente quando tenta contextualizar a ação da expedição e de Langsdorff, ou quando compara o trabalho de Langsdorff ao de outros naturalistas, quando então seu parti pris aflora com intensidade. Não é o caso de enumerar aqui, à exaustão, as passagens discutíveis, mas citarei alguns trechos. Por exemplo, ao apresentar o manuscrito 'Breve descrição da geografia física e política da Capitania de Minas Gerais', escrito, como supõe o autor, por um alto funcionário da Capitania, Boris Komissarov comenta que "o trabalho tem caráter oficial e não contém crítica ao regime vigente. Pela forma com que se relacionava com os diferentes grupos da população, deduz-se a mentalidade do autor. Era hostil aos índios, aprovava a escravatura e justificava a situação reinante dos proprietários europeus" (p. 59). Causa estranheza esperar atitude diferente de funcionário da Coroa ao redor de 1805. Num 
outro momento, Komissarov refere-se ao texto do capitão-mor de Diamantina, intitulado 'Descrições relativas às nações indígenas que habitam dentro do Distrito Diamantino e seus setores', e chega a afirmar (p. 77), de forma anacrônica e 'presentista', que o capitão "não chegou a compreender que o roubo, a embriaguez e a prostituição, de que eram incriminados os índios, eram conseqüências da política colonizadora”. E, julgando a partir de parâmetros bastante recentes, critica as sugestões do autor do manuscrito, ao afirmar que o mesmo argumentara "que eles (os índios) deveriam viver em áreas reservadas e assimilar a civilização branca, quando estas eram as medidas que apressavam seu exterminio" (grifos meus).

Ao tratar de Langsdorff, sua admiração é tal que chega a apresentá-lo como visionário: "no local recomendado por ele para a nova capital, situa-se hoje Belo Horizonte" (p. 50). Tem-se a impressão de que Komissarov assume integralmente a visão de Langsdorff, sem distanciamento crítico: "Langsdorff percebeu a miséria de grande parte da população do Brasil, a estagnação no setor da economia e as falhas do governo. Registrou a ausência de estradas, a falta de habilidade no tratamento das terras e do subsolo, a má administração de funcionários indolentes. Apesar disso, amava o Brasil. ... Foi com sinceridade que anotou no diário que lhe arrebentava o coração verificar, a cada instante, o quão rico poderia ser o país e como era mal administrado. Levado pela tradição, ligou o atraso econômico do Brasil aos seus imensos recursos naturais, ao caráter próprio dos brasileiros e à sua ignorância" (p. 16). Em certos trechos, isso o leva a fazer afirmações, no mínimo, bastante ingênuas, como à p. 17: "sua disposição em atuar no meio em que vivia transmitiu às suas observações um caráter especial, tornando-as mais profundas. Nisso difere o seu diário das produções de europeus que viajaram pelo Brasil. É importante esclarecer que o envolvimento de Langsdorff com o futuro do país não era condicionado por interesses politicos ou econômicos da monarquia russa. Viajante a serviço da Rússia, pôde julgar com objetividade a influência de outros países no Brasil, os métodos da administração e o desenvolvimento econômico" (grifos meus). No entanto, esse aspecto talvez seja apenas a expressão, uma vez mais, da constante alteridade, do longo e aparentemente insolúvel confronto entre as visões 'locais' e aquelas 'estrangeiras', que permanecem e se manifestam até mesmo numa simples apresentação de acervos documentais.

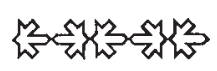

